This item was submitted to Loughborough's Research Repository by the author.

Items in Figshare are protected by copyright, with all rights reserved, unless otherwise indicated.

\title{
How do different competing species influence the response of Betula pubescens Ehrh. to browsing?
}

PLEASE CITE THE PUBLISHED VERSION

http://dx.doi.org/10.1016/j.baae.2005.05.004

\section{PUBLISHER}

(c) Gesellschaft für Ökologie. Published by Elsevier Gmbh.

VERSION

AM (Accepted Manuscript)

LICENCE

CC BY-NC-ND 4.0

\section{REPOSITORY RECORD}

Millett, Jonathan, A.J. Hester, P. Millard, and A.J.S. McDonald. 2019. "How Do Different Competing Species Influence the Response of Betula Pubescens Ehrh. To Browsing?”. figshare.

https://hdl.handle.net/2134/13432. 
This item was submitted to Loughborough's Institutional Repository (https://dspace.lboro.ac.uk/) by the author and is made available under the following Creative Commons Licence conditions.

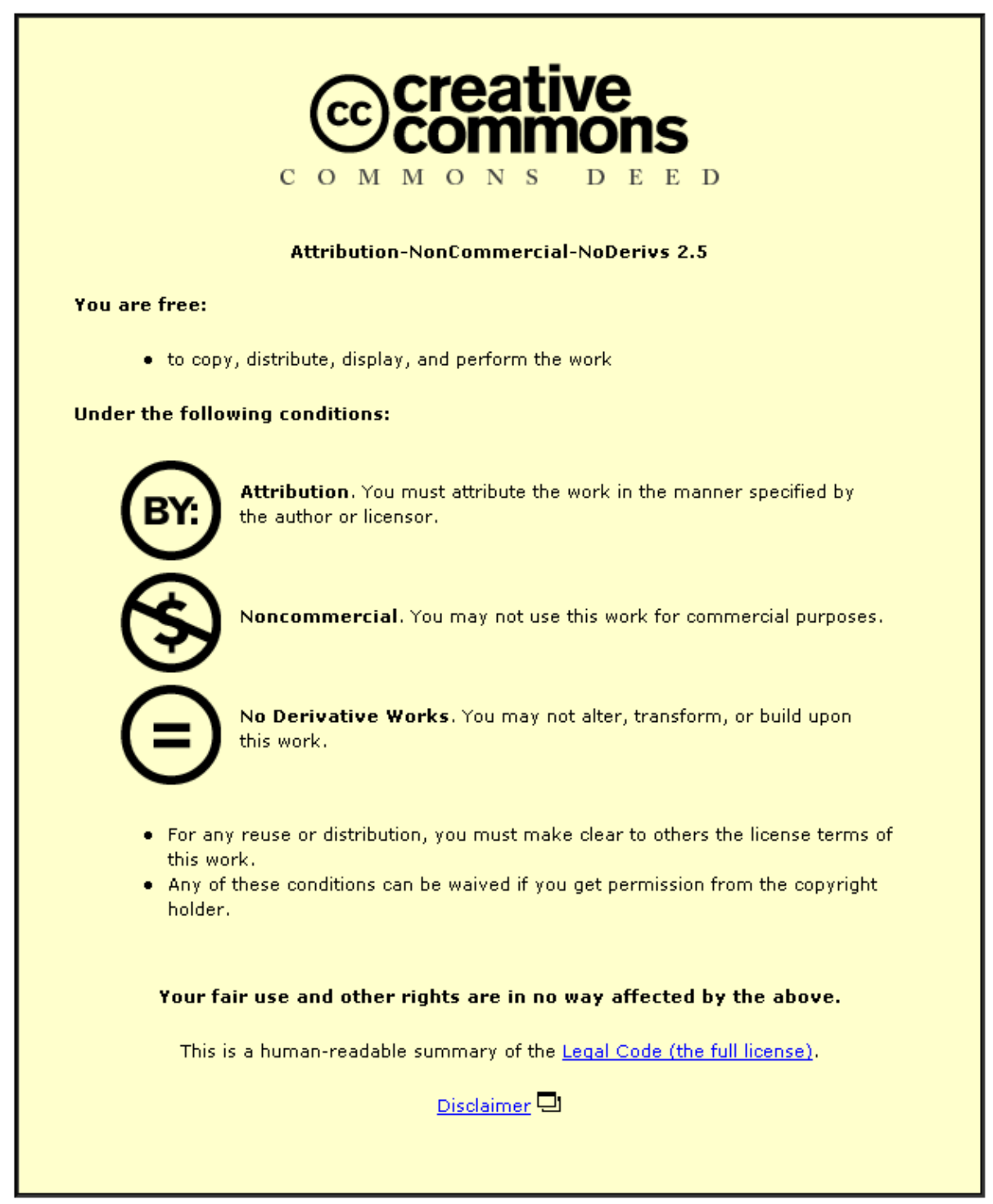

For the full text of this licence, please go to: http://creativecommons.org/licenses/by-nc-nd/2.5/ 


\section{How do different competing species influence the response of Betula pubescens Ehrh. to browsing?}

J. Millett ${ }^{1,2, *}$, A.J. Hester ${ }^{1}$, P. Millard ${ }^{1}$ and A.J.S. McDonald ${ }^{2}$

${ }^{1}$ The Macaulay Institute, Craigiebuckler, Aberdeen, AB15 8QH

${ }^{2}$ School of Biological Science, Department of Plant and Soil Sciences, Aberdeen University, Aberdeen

* Present address: Deanery of Sciences and Social Sciences, Liverpool Hope University College, Hope Park, Liverpool, L16 9JD.

* Corresponding Author. E-mail: milletj@hope.ac.uk; phone: (+44) (0)151 2912174; fax: $(+44)(0) 151$

Running title: Response of $B$. pubescens to competition and browsing

Number of words:

Altogether: 5182

Title: 14

Abstract: 268 


\begin{abstract}
When attempting to expand existing woodland through natural regeneration, herbivory and competition from the existing vegetation may impede the regenerating saplings. This work addresses how browsing and competition with other vegetation interact to drive sapling growth and morphology of the widespread tree species B. pubescens.

We took above-ground morphological measurements of $B$. pubescens saplings within an intimate mosaic of Calluna vulgaris and Molinia caerulea, comparing saplings growing with each of the two plant species under three different red deer (Cervus elaphus) densities, allowing comparison of different levels of both past and present levels of browsing damage.
\end{abstract}

Saplings growing in $M$. caerulea dominated vegetation responded to reduced browsing with faster growth than those growing in C. vulgaris dominated vegetation. However, we found that when natural browsing levels were high, browsing masked any differences in inter-specific interactions between plant species. We propose that, in regeneration schemes where deer densities are reduced, these differences should confer a competitive advantage to saplings growing with $M$. caerulea over those growing with $C$. vulgaris. Additionally, our results highlight the importance of browsing history, rather than just current browsing levels, in determining sapling growth responses under different herbivore management regimes.

This study highlights the importance of multi-factor interactions in determining plant growth and morphology under different conditions. In particular we identify the prevalence of interactions between competition, herbivory and time, as determining the potential growth and morphology of B. pubescens saplings in regeneration areas. This has important implications for the management of sites where browsing impedes the natural 
regeneration of trees and shrubs, or where herbivore densities have been reduced to encourage woodland regeneration.

Key Words: above-ground plant interactions; Betula pubescens; browsing; competition; forest regeneration; herbivory; semi-natural woodland

\section{Introduction}

In heavily grazed systems successful tree establishment is a rare occurrence (Hester, Mitchell \& Kirby 1996; Pigott 1983). Direct and indirect effects of browsing can result in morphological (Bergström \& Danell 1987; Hester et al. 1996; Van Hees, Kuiters \& Slim 1996), physiological (Millard, Hester, Wendler, \& Baillie 2001), and induced chemical (Hol et al. 2004, Bryant, Danell, Provenza, Reichardt, Clausen et al. 1991a; Bryant, Provenza, Pastor, Reichardt, Clausen et al. 1991b; Bryant, Kuropat, Reichardt \& Clausen 1991c; Tallamy \& Raup 1991) sapling responses. Inter- and intra-specific plant associations also influence tree sapling establishment success (Berkowitz, Canham \& Kelly 1995; Gordon \& Rice 2000). In forest systems, competition with surrounding vegetation, as well as other trees, has been shown to be important at all stages of woodland development (Goldberg \& Barton 1991; Steven 1991; Mallik 2003; Scott, Welch, Thurlow \& Elston 2000). While the responses of plants to herbivory or competition have been widely studied, the interactions between browsing impacts and competitive associations have been little studied, yet this is highly relevant for forest management as the combined effects on sapling growth and establishment success are not always predictable (Crawley 1997; Augustine \& McNaughton 1998; Olofsson, Moen \& Oksanen 2002).

From the few studies carried out to date, it appears that interactions with other plants can alter the effect of browsing on tree sapling survival and development (Edenius, Danell \& Bergström 1993; Hjältén, Danell \& Ericson 1993). The relationships are not linear and may 
depend on the stage of development (Meiners \& Handel 2000) or the relative influence of the forest canopy (Harmer 2001). Hjältén et al. (1993), for example, found that the ability of $B$. pubescens to compensate after different types of browsing damage (leader removal and defoliation) decreased with increasing competition. However, in Acer rubrum and Quercus palustris seedlings, Meiners et al. (2000) found an interaction between competition and herbivory for seedling mortality, but not for growth. Harmer (2001) also reported no effect of competition removal on the growth of broadleaved species (Acer pseudoplatanus, Fraxinus excelsior, Fagus sylvatica and Quercus robur) under an existing woodland canopy. What these studies do not address, however, is possible species-specific differences in the effect of competition and the interactive effect of browsing damage on such differences.

The aim of this field study was to address how browsing and competition interact to drive growth and morphology of the tree species Betula pubescens growing with two contrasting competing plant species (Calluna vulgaris (L.) Hull and Molinia caerulea (L.) Moench), under differing levels of browsing damage. Betula pubescens is widely distributed in Europe and is the dominant component of many semi-natural forest systems and a co-occurring species in many other semi-natural woodland systems (Atkinson 1992). M. caerulea and C. vulgaris are both widespread through Northern Europe, and are dominant in many of the upland areas in which regeneration of semi-natural woodland occurs. They have contrasting growth habits; C. vulgaris is an evergreen ericaceous shrub whereas $M$. caerulea is a deciduous tussock grass (Gimingham 1960; Taylor, Rowland \& Jones 2001). Therefore, it is hypothesised that their influences on the above-ground environment of regenerating $B$. pubescens saplings will be different, with Calluna providing a greater barrier to growth than Molinia due to its increased interference with the light environment. Below-ground interactions are also hypothesised to be different (Heil \& Bruggink 1987), but this was not part of this study. We took above-ground morphological measurements of B. pubescens 
saplings growing in C. vulgaris or M. caerulea, under different levels of browsing damage, to test the hypothesis that the response of $B$. pubescens saplings to browsing is influenced by the species of competing vegetation.

\section{Materials and methods}

\section{Site descriptions}

This study was conducted within an upland area in the Scottish Highlands (UK grid reference: NN479875). This area was selected due to its abundance of Betula pubescens saplings (hereafter Betula) which were regenerating in Molinia caerulea (hereafter Molinia) and Calluna vulgaris (hereafter Calluna) dominated vegetation, and the availability of information on present and past grazing pressure (NCC 1989). The main vegetation type in this area is Calluna and Molinia dominated heath, with very little remaining semi-natural woodland, due to a long history of heavy browsing by high densities of deer and sheep (NCC 1989). This study was conducted within two adjacent land management units (Creag Meagaidh and Ardverikie), with contrasting deer management strategies but similar vegetation, topography and soils. At both sites the soils are predominantly humic podzols overlaying acidic schists and granulites (NCC 1989). The main deer species in the area is the red deer (Cervus elaphus), but roe deer (Capreolus capreolus) are also present in small numbers. Creag Meagaidh has been managed since 1985 for regeneration of woodland via reduction in deer numbers and removal of sheep (NCC 1989). Ardverikie is a traditionally managed sporting estate, with relatively high deer densities which are maintained through winter-feeding. The boundary with Creag Meagaidh is fenced with an open-ended fence, which allows limited movement of deer between the estates. The Ardverikie estate supports distinctly higher densities of deer than Creag Meagaidh, giving a deer density gradient both within and between these two adjacent land management units. 


\section{Site/plot choice}

The strong gradient of herbivore densities present in the area enabled us to compare the effect of different levels of browsing damage on naturally regenerating Betula pubescens saplings. Saplings were sampled from three sites chosen for their contrasting levels of deer usage; two

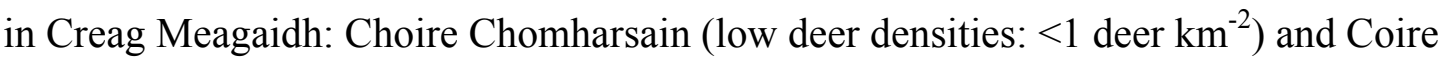
Chrannaig (intermediate deer densities: approximately 6 deer $\mathrm{km}^{-2}$ ) (deer densities based on data in Putman (2003)) and one in Ardverikie (high deer densities: approx. 20 deer km ${ }^{-2}$ (P.Duncan, pers. comm.)). Accordingly, throughout this paper 'site' and 'deer density' are analogous. Within each site, saplings were sampled from three replicate $100 \mathrm{~m}^{2}$ plots. The criterion for selection of plots was the presence of Betula regeneration at or below browsing height $(<2 \mathrm{~m})$ growing within an area where Calluna and Molinia coexist in small (approximately 1-4 $\mathrm{m}^{2}$ ) discrete patches, rather than in continuous stands. Equal numbers of saplings were sampled from each of these two vegetation types within each plot. We measured local soil moisture and light environment, as part of site characterisation, to assess whether there were any consistent differences between the two vegetation types in terms of these two key physical characteristics. Soil cores $(10 \mathrm{~cm}$ in diameter) were taken at random from each vegetation type at each plot (one per vegetation type per plot (total of 18)). Each core was placed within the vegetation type using random methods. Soil was taken to a depth of $15 \mathrm{~cm}$. Percentage moisture was calculated as the difference in soil weight before and after drying ( 72 hours at $28^{\circ} \mathrm{C}$ ). Light measurements were taken at two different times of the year ( $25^{\text {th }}$ April and $15^{\text {th }}$ August). Measurements of photosynthetic photon flux density $(400-700 \mathrm{~nm})(\mathrm{PPFD})$ and red to far-red $(660 / 730 \mathrm{~nm})$ photon flux ratio (r:fr) were taken above and within the canopy of Molinia and Calluna at ten randomly assigned points within plot 1 in Choire Chomharsain (i.e. ten measurements for each vegetation type), using a PAR Quantum sensor (SKP 210, Skye Instruments Ltd.) and 660/730 sensor (SKR 110, Skye Instruments Ltd.). 


\section{Sapling sampling procedure}

Saplings were measured between $1^{\text {st }}$ and $31^{\text {st }}$ August 2002 (end of summer growing season); the same plots were re-sampled between $1^{\text {st }}$ and $14^{\text {th }}$ May 2003 (at bud-burst and before new shoot growth for 2003). This was to allow for any differential effects due to seasonality of deer use. Within each $100 \mathrm{~m}^{2}$ plot, 15 trees from each vegetation type were selected, using randomly generated grid coordinates and carefully searching for the closest sapling to that point, giving 45 trees per site. The following morphological measurements were taken in 2002: height of sapling; length; number of main stems; stem diameter; number of branches; leader length (current years growth from the apex of the main stem); distance to lowest branch; number of terminal long shoots; number of lateral long shoots; number of short shoots; number of leaves and canopy cover (canopy cover $=$ area of ellipse $=\pi a b / 4$, where $a=$ distance between the edges of the widest part of the canopy and $b=$ the distance between the edges perpendicular to $a$ ). A sub-sample of 16 sapling trees (eight from each vegetation type) per plot was removed and aged using growth ring counts, to give a mean sapling age per vegetation type per plot. In spring 2003 sampling period, the following measurements were made: height of sapling; length; number of main stems; stem diameter; number of branches; leader length; distance from the ground to the lowest branch; number of terminal long shoots; number of lateral long shoots; number of short shoots; number of leaves and canopy cover. The percentage of shoots browsed/unbrowsed was also recorded for each sapling. In 2002, previous and current years browsing were recorded. In May 2003, only browsing of 2002 growth was recorded (this represented a full year of browsing of 2002 shoots). The two measurements analysed here are pre-2002 browsing (from 2002 recording) and 2002 browsing (from May 2003 recording). The severity of browsing was calculated as a percentage of all the shoots present in that year. 


\section{Data analysis}

Data were analysed using ANOVA in Genstat $6^{\text {th }}$ Edition (Lawes Agricultural Trust 2002).

For sapling morphology, treatments were site $\mathrm{x}$ surrounding vegetation species $\mathrm{x}$ year.

Blocking was applied using 'plot'; for light measurements treatments were vegetation species $\mathrm{X}$ measurement location (above- or within vegetation) $\mathrm{x}$ time (spring or autumn). Where data did not meet the assumptions required for the use of ANOVA they were transformed using a Log or angular transformation as appropriate (Table 1). R:fr ratio data were antilog transformed before analysis.

\section{Results}

\section{Effects of competing plant species}

There were significant differences in the majority of the measurements, between saplings growing in the two vegetation types (Table 1). Values were consistently higher for saplings growing in Molinia dominated vegetation; saplings had larger stem diameters, more leaves, more terminal and lateral long shoots, more short shoots; larger canopy cover, more branches/cm of length and a larger proportion of lateral long shoots (Fig. 1, Fig. 2 and Fig. 3). Additionally, sapling ages did not differ significantly between Calluna and Molinia dominated areas at the high deer density site. However, there were significant differences between sites. Saplings were oldest in Ardverikie, but only by a mean of 2.5 years $(x \pm \mathrm{SE}$ : low density $6.6 \pm 0.36$; intermediate $7.4 \pm 0.43$; high density $9.9 \pm 0.49$ years). The height and length of saplings was slightly lower in spring 2003 than autumn 2002, after winter browsing (Fig. 1). However, in 2003, saplings had a larger canopy cover (Fig. 1), more branches (Fig. 3), and more long and short shoots (Fig. 2).

Calluna and Molinia both reduced the PPFD and r:fr ratio, but to different extents (Table 2). There were also differences in the extent that PPFD and r:fr ratio were reduced, between spring and late summer, with differences between species in this extent. Measurement of soil 
moisture (percent weight) between the two vegetation types showed no significant differences between Molinia dominated and Calluna dominated areas $(x \pm$ SE: Molinia $26 \% \pm 2.42$;

Calluna $34 \% \pm 6.31$; t-test, $P=0.13(\mathrm{n}=10$ per vegetation type $)$ ).

There was no significant effect of vegetation type on the proportion of shoots browsed at each site $\left(\right.$ ANOVA, $\left.F_{(1,520)}=0.49, P=0.942\right)$.

\section{Effects of deer density}

There were significant differences between sites in all B. pubescens morphological measurements except the number of branches/cm and the total number of long shoots (Table 1). Measurements that relate to the size of the saplings were consistently highest for saplings at the low deer density site and lowest at the high deer density site (Fig. 1). The same differences applied to the number of short shoots (Fig. 2). However, the trend was reversed for leader length (Fig. 3) and the number of long shoots (Fig. 2); with the high density site > intermediate site $>$ low deer density site.

There was a significant effect of site on the proportion of shoots browsed (Fig. 4). Pre-2002 browsing was highest for saplings at the high deer density site, intermediate at the intermediate deer density site and lowest for saplings at the low deer density site, which also received the least browsing in 2002. However, the highest levels of 2002 browsing were at the intermediate deer density site.

There was a significant difference between years, in the amount of browsing damage recorded. Pre-2002 browsing was lower than the browsing that occurred during 2002 (Fig. 4). There were significant site $\mathrm{x}$ vegetation type interactions for the following measurements: number of leaves; branches; terminal long shoots; total long shoots; short shoots and branches per $\mathrm{cm}$ of length (Table 1). The difference between saplings in Calluna dominated and Molinia dominated vegetation consistently increased from high deer density $<$ intermediate $<$ 
low density sites, with the highest values occurring in saplings growing in Molinia dominated vegetation in the low deer density site (Fig. 1, Fig. 2, and Fig. 3).

\section{Discussion}

Complex multi-factor interaction effects are common in natural systems (Storch \& Gaston 2004), yet the majority of sapling growth studies to date have concentrated on the main effects or, at most, two-way interactions. In this study we investigated interaction effects between three drivers of plant morphology: herbivore density $\mathrm{x}$ vegetation (competition) $\mathrm{x}$ year, with the aim of providing a more integrative perspective on how the system functions. We found many strong, significant interactions between the measured factors, illustrating the importance of interactions between herbivory, vegetation type and time on B. pubescens growth and morphology. This highlights the importance of explicitly considering multi-way interaction effects in natural systems before designing potentially over-simplistic management regimes.

While the level of herbivore pressure dominates development from heath to woodland, interspecific competition can have a significant influence on tree sapling growth and morphological development. The response of Betula saplings to browsing was clearly modified by the species of surrounding vegetation, with Calluna appearing to inhibit sapling re-growth to a greater extent than Molinia. However, we propose that species-specific competitive differences between $C$. vulgaris and $M$. caerulea are only important after herbivore damage is reduced to a sufficient extent. This is an important finding in relation to predicting the impacts of reducing herbivore numbers on sapling growth within different vegetation types. For example, when managing to regenerate areas of semi-natural woodland, the extent to which saplings should be protected from herbivory may be dependent on the vegetation into which they are growing. From our results, once established, saplings growing 
within Calluna dominated vegetation will need to be protected from heavy browsing for significantly longer than those growing within Molinia, to allow them to grow above the reach of browsing animals.

The non-manipulative nature of this study gives the benefit of recording saplings growing insitu in an undisturbed natural system, but this can also be criticised in terms of control of between-site variability. Our three sites were relatively close to each other (within $3 \mathrm{~km}$ ) and had previously been managed in the same way. With the exception of deer densities the characteristics of the sites were similar (e.g. elevation, soils, climate) (NCC 1989, Stewart 1996). Additionally, the differences in deer density were due to anthropogenic causes and not due to any other differences between sites. Therefore, it seems likely that the measured sapling differences between the three selected sites were primarily driven by deer density and were not confounded by any other major site-related factors.

Although the mechanisms of competition and reasons for differences between plants cannot be reliably determined from this field study alone, our data point to one key mechanism: light. The different growth strategies of Molinia and Calluna resulted in measured differences in the light environment, which is likely to cause differences in sapling morphology due to light quality (r:fr ratio) or differences due to differential resource restriction (PPFD). Additionally, although below-ground variables and interactions were not measured in this study, they undoubtedly also influence above-ground responses and vice-versa (Casper \& Jackson 1997; Tilman 1997; Millard et al. 2000; Hester, Millard, Baillie \& Wendler 2004). From previous work on ericaceous species, we propose that below-ground inhibition of growth through allelopathy is also likely to have contributed to the poorer sapling growth within this vegetation type as compared to within Molinia (Mallik 2003). Furthermore, the strength of below-ground competition may also change with differences in resource availability (Casper 
et al. 1997) which again has been hypothesised to interact with herbivore browsing, for example by reducing soil $\mathrm{N}$ availability (Harrison \& Bardgett 2003).

Although our results indicate reduced competition from Molinia as compared to Calluna for established birch saplings, it is important to note that this may differ for the early seedling establishment phase. Bokdam \& Gleichman (2000) found greater Betula seedling establishment in Calluna-dominated than Molinia-dominated vegetation. Kinnaird (1974) also found lower densities of Betula seedlings in grass (species not specified) communities than heather communities. If we consider the scales at which these two different stages of tree growth operate, it is possible that Molinia may provide greater resistance to seed germination and seedling establishment due to the relatively impenetrable 'mat' of dead leaves, a result of the senescence of previous years' growth. This may impede seeds from reaching the ground and, for any that do, will greatly reduce light (and possibly moisture) reaching the small seeds/seedlings. This is supported by results of germination trials by Stewart (1996) who found that Betula pubescens seed germination was restricted to a greater degree by Molinia than by Calluna, although germination success appeared to be most dependent on the creation of gaps (by deer).

In conclusion, management prescriptions often concentrate on single drivers of ecosystem processes (for example: herbivory, competition (weeds), eutrophication). When regenerating woodland in areas with a history of high levels of herbivore densities it is browsing that is normally identified as the largest hindrance to successful tree establishment. However, our study shows that the growth and morphology of regenerating tree saplings is also dependent on interaction effects with surrounding vegetation when herbivore numbers are reduced and this is highly relevant for choice of sites and predictions about the likely consequences of herbivore management options. 


\section{ACKNOWLEDGEMENTS}

We would like to thank Scottish Natural Heritage and Ardverikie Estate for allowing access to field sites. We would particularly like to thank Peter Duncan for his help while at Creag Meagaidh. Glenn Iason and two anonymous referees gave extremely useful comments on the manuscript. The Macaulay Development Trust funds JM. Thanks to SEERAD for funding AJH and PM.

\section{REFERENCES}

Atkinson, M.D., (1992). Biological flora of the British Isles No. 175. Betula pendula Roth (B. verrucosa Ehrh. And B. pubescens Ehrh. Journal of Ecology, 80, 837-870.

Augustine, D.J., \& McNaughton, S.J., (1998). Ungulate effects on the functional species composition of plant communities: herbivore selectivity and plant tolerance. Journal of Wildlife Management, 62, 1165-1183.

Bergström, R., \& Danell, K., (1987). Effects of simulated winter browsing by moose on morphology and biomass of 2 birch species. Journal of Ecology, 75, 533-544.

Berkowitz, A. R., Canham, C. D., \& Kelly, V. R. (1995). Competition vs. facilitation of tree seedling growth and survival in early successional communities. Ecology, 76, 1156-1168.

Bokdam, J., \& Gleichman, J. M. (2000). Effects of grazing by free ranging cattle on vegetation dynamics in a continental north-west European heathland. Journal of Applied Ecology, 37, 415-431.

Bryant, J.P., Danell, K., Provenza, F.D., Reichardt, P.B., Clausen, T.P., \& Werner, R.A. (1991a). Effects of mammal browsing on the chemistry of deciduous woody plants. In: D. Tallamy \& M.J. Raup (Eds.) Phytochemical induction by herbivores (pp.135-154). New York: Wiley.

Bryant, J.P., Provenza, F.D., Pastor, J., Reichardt, P.B., Clausen, T.P., \& du Toit, J.T. (1991b). Interactions between woody plants and browsing animals mediated by secondary metabolites. Annual Review of Ecology and Systematics, 22, 431-446.

Bryant, J.P., Kuropat, P.J., Reichardt, P.B., \& Clausen, T.P. (1991c). Chemically mediated interactions between woody plants and browsing mammals. Journal of Range Management, 45, 18-24.

Casper, B. B., \& Jackson, R. B. (1997). Plant competition underground. Annual Review of Ecology and Systematics, 28, 545-570.

Crawley, M.J. (1997). Plant-herbivore dynamics. In: M.J. Crawley (Ed.) Plant Ecology (pp. 401-474 ). Oxford: Blackwell Science Ltd. 
Edenius, L., Danell, K., \& Bergström, R. (1993). Impact of herbivory and competition on compensatory growth in woody plants: winter browsing by moose on Scots pine. Oikos, 66, 286-292.

Gimingham, C.H. (1960). Biological Flora of the British Isles. Calluna vulgaris (L.) Hull. Journal of Ecology, 48 455-483.

Goldberg, D. E., \& Barton, A. M. (1991). Patterns and consequences of interspecific competition in natural communities: a review of field experiments with plants. The American Naturalist, 139, 771-801.

Gordon, D. R., \& Rice, F. J. (2000). Competitive suppression of Quercus douglasii (Fagacea) seedling emergence and growth. American Journal of Botany, 87, 986-994.

Harmer, R. (2001). The effect of plant competition and simulated summer browsing by deer on tree regeneration. Journal of Applied Ecology, 38, 1094-1103.

Harrison, K. A., \& Bardgett, R. D. (2003). Browsing by red deer negatively impacts on soil nitrogen availability in regenerating native forest. Soil Biology and Biochemistry, 36, 115126.

Heil, G. W., \& Bruggink, M. (1987) Competition for nutrients between Calluna vulgaris (L.) Hull and Molinia caerulea (L.) Moench. Oecologia, 73, 105-107.

Hester, A. J., Millard, P., Baillie, G. J., \& Wendler, R. (2004). How does timing of browsing affect above- and below-ground growth of Betula pendula, Pinus sylvestris and Sorbus aucuparia? Oikos 105, 536-550.

Hester, A. J., Mitchell, F. J. G., \& Kirby, K. J. (1996). Effects of season and intensity of sheep grazing on tree regeneration in a British upland woodland. Forest Ecology and Management, 88, 99-106.

Hjältén, J., Danell, K., \& Ericson, L. (1993). Effects of simulated herbivory and intraspecific competition on the compensatory ability of birches. Ecology, 74, 1136-1142.

Hol, W. H. G., Macel, M., van Veen, J. A., \& van der Meijden, E. (2004). Root damage and aboveground herbivory change concentration and composition of pyrrolizidine alkaloids of Senecio jacobaea. Basic and Applied Ecology, 5, 253-260.

Kinnaird, J. W. (1974). Effect of site conditions on the regeneration of birch (Betula pendula and pubescens Ehrh.). Journal of Ecology, 62, 467-472.

Lawes Agricultural Trust. (2002) Genstat. 6[6.2.0.235].

Mallik, A. U. (2003). Conifer regeneration problems in boreal and temperate forests with ericaceous understory: Role of disturbance, seedbed limitation, and keystone species change. Critical Reviews in Plant Sciences, 22, 341-366.

Meiners, S. J., \& Handel, S. N. (2000). Additive and non-additive effects of herbivory and competition on tree seedling mortality, growth and allocation. American Journal of Botany, 87, 1821-1826. 
Millard, P., Hester, A. J., Wendler, R., \& Baillie, G. J. (2001). Interspecific defoliation responses of trees depends on sites of winter nitrogen storage. Functional Ecology, 15, 535543.

NCC. (1989). Creag Meagaidh National Nature Reserve, First Management Plan 1989 1993. Nature Conservancy Council Report. Edinburgh.

Olofsson, J., Moen, J \& Oksanen, L. (2002). Effects of herbivory on competition intensity in two arctic-alpine tundra communities with different productivity. Oikos, 96, 265-272.

Pigott, C. D. (1983). Regeneration of oak-birch woodland following exclusion of sheep. Journal of Ecology, 71, 629-646.

Putman, R. J. (2003). An Analysis of Trends in Deer Populations and in the Vegetation of Creag Meagaigh National Nature Reserve 1986-2001. Scottish Natural Heritage.

Scott, D., Welch, D., Thurlow, M., \& Elston, D.A. (2000). Regeneration of Pinus sylvestris in a natural pinewood in NE Scotland following reduction in grazing by Cervus elaphus. Forest Ecology and Management, 130, 199-211.

Steven, D. D. (1991). Experiments on mechanisms of tree establishment in old-field succession: seedling emergence. Ecology, 72, 1066-1075.

Stewart, F. (1996). The effects of red deer (Cervus elaphus) on the regeneration of birch (Betula pubescens) woodland in the Scottish Highlands. PhD thesis, Aberdeen University, Aberdeen.

Storch, D., \& Gaston, K., J. (2004). Untangling ecological complexity on different scales of space and time. Basic and Applied Ecology, 5, 389-400.

Tallamy, D.W. \& Raup, M.J. (1991). Phytochemical induction by herbivores. John Wiley \& Sons, Chichester.

Taylor, K., Rowland, A.P., \& Jones, H.E. (2001). Biological flora of the British Isles No. 216. Molinia caerulea (L.) Moench. Journal of Ecology, 89 126-144.

Tilman, D. (1997). Mechanisms of plant competition. In: M.J. Crawley (Ed.), Plant Ecology (pp. 239-261). Oxford: Blackwell Science Ltd.

Van Hees, A. F. M., Kuiters, A. T., \& Slim, P. A. (1996). Growth and development of silver birch, pedunculate oak and beech as affected by deer browsing. Forest Ecology and Management, 88, 55-63. 
Table 1. Results of the full factorial univariate analysis on 10 response variables. Source of variation: $\mathrm{S}=$ site (three levels); $\mathrm{C}=$ competing plant species (2 levels); $\mathrm{Y}=$ year (2 levels). Significance values NS = not significant; $*=P<0.05 ; * *=P<0.01 ; * * *=P<0.001 . \mathrm{n}=45$ per surrounding vegetation species.

\begin{tabular}{|c|c|c|c|c|c|c|}
\hline & & Height $^{1}$ & Stem Diameter ${ }^{1}$ & Canopy Cover ${ }^{1}$ & No. Leaves ${ }^{1}$ & Total Shoots $^{1}$ \\
\hline Source & d.f. & $F$ & $F$ & $F$ & $F$ & $F$ \\
\hline $\mathrm{S}$ & 2,6 & $187.53^{\star \star \star}$ & $25.82^{\star *}$ & $168.29^{\star \star \star}$ & $42.58^{\star \star \star}$ & $66.15^{\star \star \star}$ \\
\hline C & 1,522 & $3.24^{\mathrm{NS}}$ & $17.26^{\star \star \star}$ & $8.34^{\star \star}$ & $19.43^{\star \star \star}$ & $22.42^{\star \star *}$ \\
\hline Y & 1,522 & $5.07 *$ & $1.87^{\mathrm{NS}}$ & $5.38^{\star}$ & $0.19^{\mathrm{NS}}$ & $26.22^{\star \star \star}$ \\
\hline$S \times C$ & 2,522 & $7.45^{\star \star \star}$ & $15.98^{\star \star \star}$ & $2.24^{\mathrm{NS}}$ & 6.20 ** & $8.28^{\star \star \star}$ \\
\hline$S \times Y$ & 2,522 & $8.01^{\star \star *}$ & $1.91^{\mathrm{NS}}$ & $3.98^{\star}$ & $8.66^{\star \star \star}$ & $20.28^{\star \star \star}$ \\
\hline$C \times Y$ & 1,522 & $10.43^{\star \star *}$ & $0.32^{\mathrm{NS}}$ & $0.02^{\mathrm{NS}}$ & $0.27^{\mathrm{NS}}$ & $0.81^{\mathrm{NS}}$ \\
\hline$S \times C \times Y$ & 2,522 & $15.73^{\star * *}$ & $8.75^{\star \star \star}$ & $2.08^{\mathrm{NS}}$ & $2.17^{\mathrm{NS}}$ & $1.43^{\mathrm{NS}}$ \\
\hline
\end{tabular}

\begin{tabular}{|c|c|c|c|c|c|c|}
\hline & & No. Short Shoots ${ }^{1}$ & Total Long Shoots & $\begin{array}{l}\text { No. Terminal Long } \\
\text { Shoots }^{1}\end{array}$ & No. Branches ${ }^{1}$ & Leader Length $^{1}$ \\
\hline Source & d.f. & $F$ & $F$ & $F$ & $F$ & $F$ \\
\hline$\overline{\mathrm{S}}$ & 2,6 & $107.58^{\star \star \star}$ & $0.50^{\mathrm{NS}}$ & $0.032 *$ & $37.46^{\star \star \star}$ & $53.92^{\star \star \star}$ \\
\hline C & 1,522 & $15.28^{\star \star \star}$ & $26.38^{* * *}$ & $19.88^{\star \star \star}$ & $7.59 * \star$ & $0.34^{\mathrm{NS}}$ \\
\hline Y & 1,522 & $27.57^{\star \star \star}$ & $26.89 * * *$ & $12.32^{\star \star \star}$ & $4.07^{*}$ & $82.85^{\star \star \star}$ \\
\hline $\mathrm{S} \times \mathrm{C}$ & 2,522 & $7.68^{\star \star \star}$ & $9.89 * \star *$ & $10.54^{\star \star \star}$ & 5.59 ** & $5.06^{\star *}$ \\
\hline$S \times Y$ & 2,522 & $38.08^{\star * \star}$ & $3.56^{\star}$ & $3.76^{\star}$ & $5.83^{\star *}$ & $2.37^{\mathrm{NS}}$ \\
\hline$C \times Y$ & 1,522 & $2.44^{\mathrm{NS}}$ & $0.00^{\mathrm{NS}}$ & $2.58^{\mathrm{NS}}$ & $0.85^{\mathrm{NS}}$ & $5.58 *$ \\
\hline$S \times C \times Y$ & 2,522 & $0.13^{\mathrm{NS}}$ & $2.53^{\mathrm{NS}}$ & $0.56^{\mathrm{NS}}$ & $1.19^{\mathrm{NS}}$ & $3.22^{\star}$ \\
\hline
\end{tabular}

${ }^{\mathrm{T}}$ Data $\log _{10}$ transformed before analysis 
Table 2. Results of the analysis of measurements of the light environment taken in $M$.

caerulea or C. vulgaris dominated vegetation. Presented are: (A), mean \pm standard error of photosynthetic photon flux density (400-700nm) (PPFD) and red to far-red (660/730) photon flux ratio (R:FR) of measurements taken above and within the vegetation at two different times in the year (25 $5^{\text {th }}$ April (spring) or $15^{\text {th }}$ August (autumn); and (B), result of the full factorial univariate analysis. Source of variation: $\mathrm{L}=$ location of measurement (above or within vegetation), $\mathrm{S}=$ species (C. vulgaris or $M$. caerulea); $\mathrm{T}=$ time of measurement (spring or autumn). Significance values: $*=P<0.05, * *=P<0.01, * * *=P<0.001$. r:fr data were antilog transformed before analysis.

\section{(A)}

\begin{tabular}{|c|c|c|c|c|c|c|c|c|}
\hline & \multicolumn{4}{|c|}{ PPFD } & \multicolumn{4}{|c|}{ r:fr ratio } \\
\hline & \multicolumn{2}{|c|}{ Calluna } & \multicolumn{2}{|c|}{ Molinia } & \multicolumn{2}{|c|}{ Calluna } & \multicolumn{2}{|c|}{ Molinia } \\
\hline & above & within & above & within & above & within & above & within \\
\hline Spring & $576 \pm 1.3$ & $170 \pm 2.7$ & $616 \pm 2.6$ & $457 \pm 2.8$ & $1.12 \pm 0$ & $0.96 \pm 0.01$ & $1.13 \pm 0$ & $1.08 \pm 0$ \\
\hline Autumn & $572 \pm 1.2$ & $164 \pm 1.8$ & $620 \pm 2.3$ & $265 \pm 1.5$ & $1.12 \pm 0$ & $0.61 \pm 0.02$ & $1.13 \pm 0$ & $0.61 \pm 0.02$ \\
\hline
\end{tabular}

(B)

\begin{tabular}{lrrr}
\hline & \multicolumn{2}{c}{$F$} \\
\cline { 2 - 4 } & & d.f. & \multicolumn{1}{c}{ R:FR } \\
\hline Location of measurement (above- or within vegetation) $(\mathrm{L})$ & 1,72 & $492.08^{\star \star \star}$ & $4391.52^{\star \star \star}$ \\
Vegetation species (S) & 1,72 & $63.7^{\star \star \star}$ & $84.89^{\star \star \star}$ \\
Time of Year (T) & 1,72 & $10.90^{\star \star}$ & $1271.57^{\star \star \star}$ \\
L x S & 1,72 & $25.23^{\star \star \star}$ & $58.92^{\star \star \star}$ \\
L X T & 1,72 & $10.95^{\star \star}$ & $1283.79^{\star \star \star}$ \\
S X T & 1,72 & $8.83^{\star \star}$ & $66.16^{\star \star \star}$ \\
L X S X T & 1,72 & $10.47^{\star \star}$ & $63.41^{\star \star \star}$ \\
\hline
\end{tabular}




\section{Figure legends}

Figure 1. Effect of competing species on height, length, stem diameter and number of leaves on B. pubescens saplings growing at three different sites (Mean $\pm \mathrm{SEM}, \mathrm{n}=45)$. Data presented are means of measurements taken from the same plots in August 2002 and May 2003. As indicated in Table 2 , analysis of some variables was on $\log _{10}$ transformed data. The significance of the effects are shown in Table 2. Bars with different letters above them indicate significant differences between means (Fisher's LSD, $P<0.05$ ) (where appropriate LSDs were based on transformed data, as per Table 2). Values for Calluna are represented by white bars, those for Molinia are represented by grey bars.

Figure 2. Effect of competing species on numbers of shoots on B. pubescens saplings growing at three sites (Mean $\pm \mathrm{SEM}, \mathrm{n}=45)$. Data presented are means of measurements taken from the same plots in August 2002 and May 2003. As indicated in Table 2, analysis of some variables was on $\log _{10}$, transformed data. The significance of the effects are shown in table 2. Bars with different letters above them indicate significant differences between means (Fisher's LSD, $P<0.05$ ) (where appropriate, LSDs were based on transformed data, as per Table 2). Values for Calluna are represented by white bars, those for Molinia are represented by grey bars.

Figure 3. Effect of competing species on morphological measurements of B. pubescens saplings growing at three sites (Mean $\pm \mathrm{SEM}, \mathrm{n}=45$ ). Data presented for number of branches are means of measurements taken from the same plots in August 2002 and May 2003, data presented for leader length are from 2002 measurements. As indicated in Table 2, analysis of some variables was on $\log _{10}$ transformed data. The significance of the effects are shown in Table 2. Bars with different letters above them indicate significant differences between means (Fisher's LSD, $P<0.05$ ) (where appropriate LSDs are based on transformed data, as per Table 2). Values for Calluna are represented by white bars, those for Molinia are represented by grey bars. 
Figure 4. Percentage of shoots browsed of B. pubescens saplings growing at three sites. Values are presented for two different time periods. Pre-2002 values were recorded in August 2002; 2002 values were recorded in May 2003. Means \pm SE, $n=30$. ANOVA : Site effect: (d.f. 2,6) $P=0.005$, Year: (d.f. 1,520) $P<0.001$, Site x Year: (d.f. 2,520) $P<0.001$; all other effects and interactions NS. Bars with different letters above them indicate significant differences between means (Fisher's LSD, $P<0.05$ ) 
Figure 1
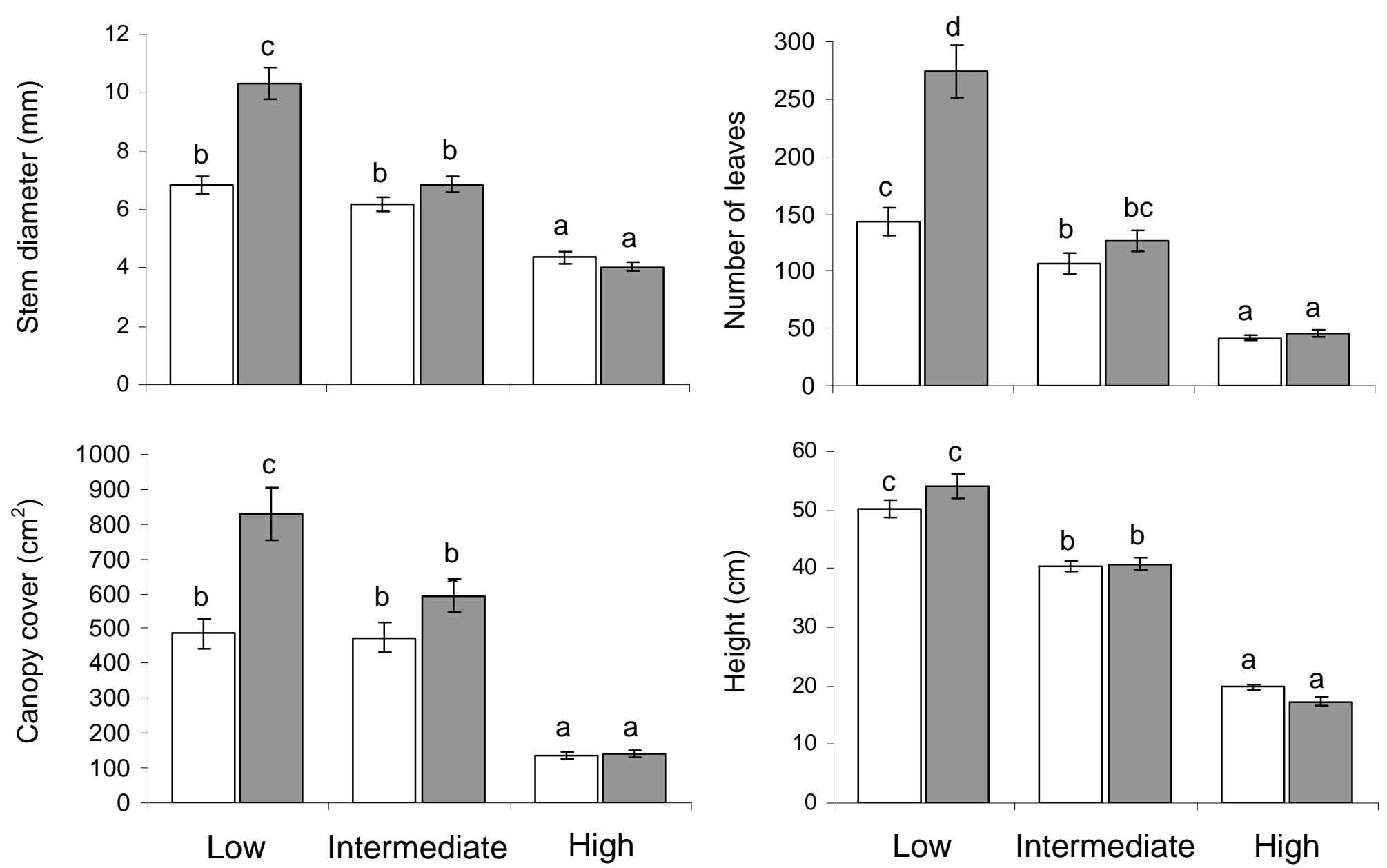

\section{Deer density}


Figure 2
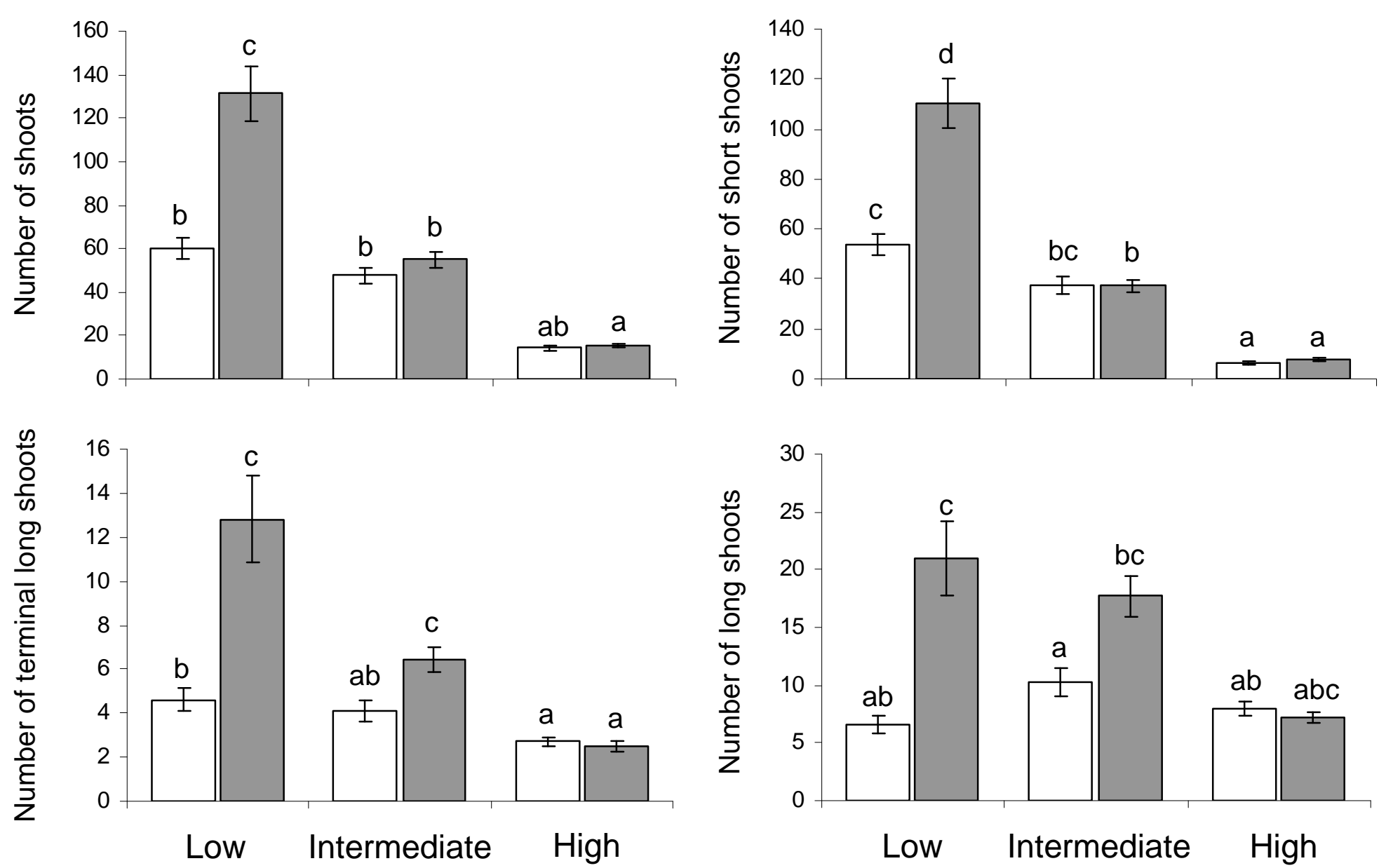

Deer density 
Figure 3
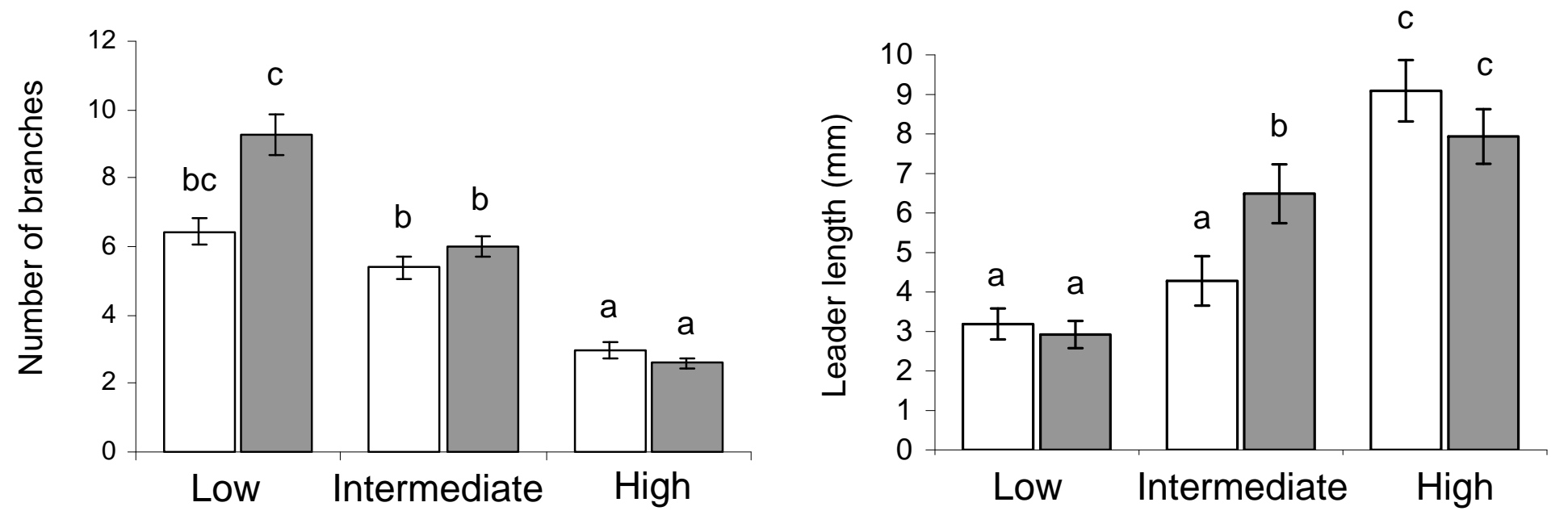

\section{Deer density}


Figure 4

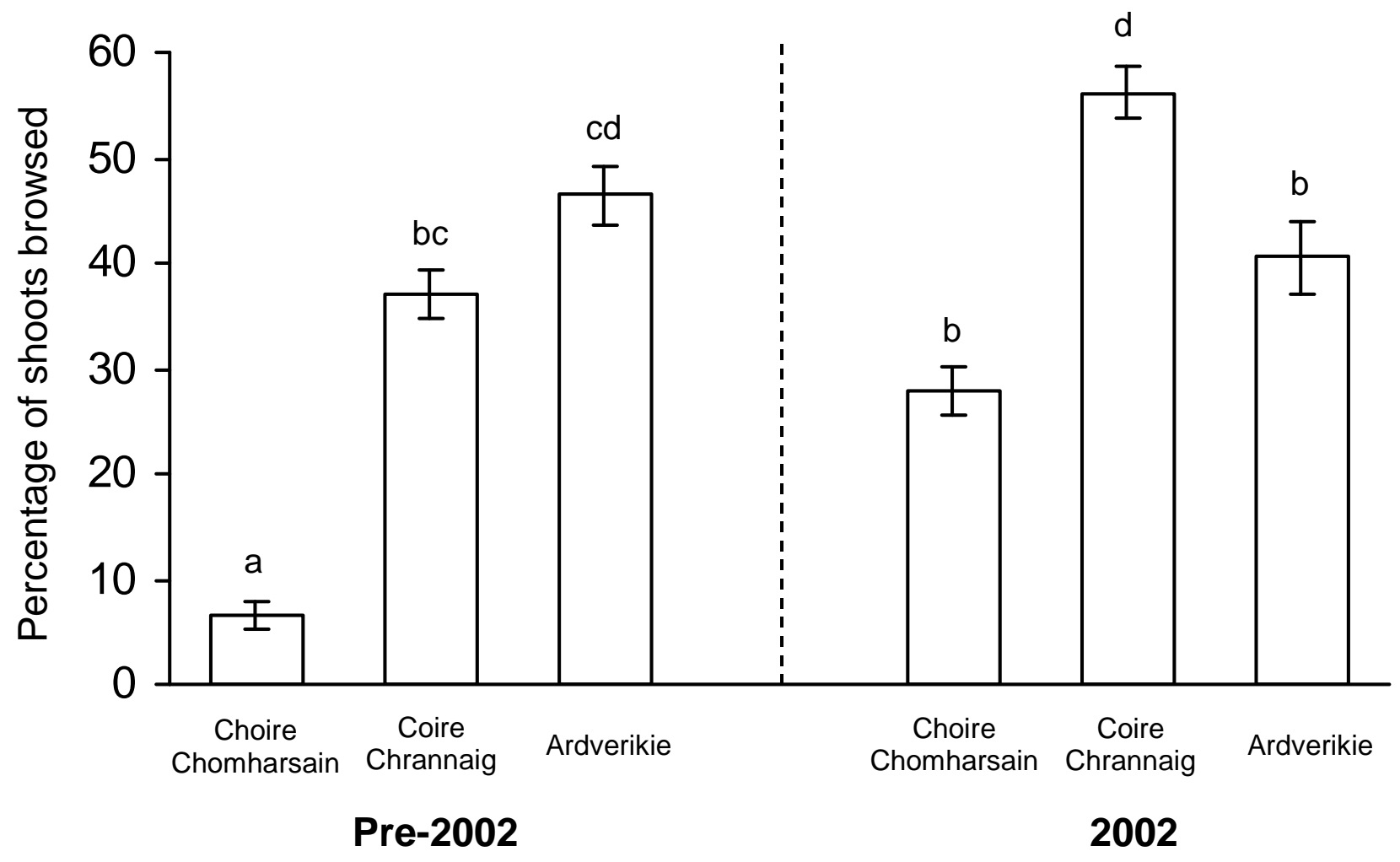

